DOI: 10.14451/2.147.43

\title{
СТАТИСТИЧЕСКИЙ АНАЛИЗ БЕЗРАБОТИЦЫ В РЕГИОНАХ СКФО
}

\section{(c) 2020 Магомадов Эмин Мухадинович}

кандидат экономических наук, доцент кафедры учета, анализа и аудита в цифровой экономике Чеченский государственный университет, Россия, Грозный

(ㄷ 2020 Абдулазимов Сайд-Магомед Зияудиевич

3 год обучения Института экономики и финансов Чеченский государственный университет, Россия, Грозный

(c) 2020 Муртазалиева Амина Хамзатовна

3 год обучения Института экономики и финансов Чеченский государственный университет, Россия, Грозный

В статье рассмотрены вопросы функционирования рынка труда в регионах Северо-Кавказского федерального округа. Рассмотрены особенности трудоизбыточности субъектов СКФО, проведен анализ занятости и безработицы субъектов округа. Даются рекомендации по поддержанию региональной занятости и регулированию напряженности на рынке труда.

Ключевые слова: СКФО, рынок труда, напряженность на рынке труда.

Целью данной статьи является статистический анализ рынка труда в СКФО, а также динамики уровня безработицы.

Объектом исследования является рынок труда СКФО.

Предметом исследования являются статистические показатели, характеризующие развитие рынка труда в среднем по России, и в СКФО в частности.

В соответствии с поставленной целью решена задача - провести сравнительный анализ рынка труда в России и в отдельном округе на примере регионов СКФО.

Для того, чтобы оценить ситуацию на рынке труда необходимо учитывать не только аб- солютную численность занятых и безработных. Следует также оценить уровень безработицы и уровень занятости, которые определяются как отношение соответствующей категории рабочей силы к численности экономически активного населения

Проанализируем динамику численности экономически активного населения в среднем по России и в регионах Северо-Кавказского федерального округа (таблица 1). Анализ данных таблицы 1 говорит о неустойчивой динамике численности экономически активного населения, как в России, так и в регионах СевероКавказского федерального округа. Для сравнения особенностей изменения экономической

Таблица 1. Численность экономически активного населения (тысяч человек; в среднем за год)

\begin{tabular}{|l|c|c|c|c|c|c|c|c|c|c|}
\hline & 2008 & 2009 & 2010 & 2011 & 2012 & 2013 & 2014 & 2015 & 2016 & 2017 \\
\hline Российская Федерация & 75757 & 75658 & 75440 & 75779 & 75676 & 75529 & 75428 & 76588 & 76636 & 76109 \\
\hline $\begin{array}{l}\text { Северо-Кавказский } \\
\text { федеральный округ }\end{array}$ & 4279 & 4387 & 4351 & 4434 & 4485 & 4525 & 4544 & 4492 & 4535 & 4559 \\
\hline Республика Дагестан & 1291 & 1272 & 1227 & 1359 & 1329 & 1320 & 1325 & 1301 & 1335 & 1360 \\
\hline Республика Ингушетия & 184 & 228 & 233 & 191 & 202 & 201 & 212 & 223 & 231 & 251 \\
\hline $\begin{array}{l}\text { Кабардино-Балкарская } \\
\text { Республика }\end{array}$ & 405 & 412 & 403 & 368 & 385 & 423 & 436 & 427 & 432 & 433 \\
\hline $\begin{array}{l}\text { Карачаево-Черкесская } \\
\text { Республика }\end{array}$ & 199 & 214 & 209 & 233 & 238 & 225 & 227 & 217 & 215 & 210 \\
\hline $\begin{array}{l}\text { Республика Северная } \\
\text { Осетия-Алания }\end{array}$ & 353 & 365 & 372 & 358 & 352 & 345 & 340 & 329 & 324 & 333 \\
\hline Чеченская Республика & 473 & 549 & 544 & 551 & 597 & 649 & 633 & 618 & 621 & 621 \\
\hline Ставропольский край & 1374 & 1347 & 1364 & 1375 & 1383 & 1362 & 1372 & 1377 & 1377 & 1352 \\
\hline
\end{tabular}


активности населения рассмотрим значения относительных уровней соответствующего показателя (таблица 2).

Уровни экономически активного населения показывают тенденцию к росту как в целом по России, так и в Северо-Кавказском федеральном округе. По Чеченской Республике уровень экономически активного населения (участия в рабочей силе) в 2010 году был близок к уровню средних значений по СКФО - около 65\%. В дальнейшем этот показатель рос быстрее, чем в среднем по России - до 76,9\% в 2013 году.

В 2017 году уровень участия в рабочей силе по Чеченской Республике начал снижение и сравнялся со среднероссийским значением, однако, падение уровня экономической активности населения в 2017 году продолжилось.

Данные таблицы показывают незначительный рост в последние годы численности заня- тых в экономике в СКФО и, в частности, в Чеченской Республике - рост более чем в 2 раза с 2008 по 2017 годы.

Сравним данные уровней безработицы в Чеченской Республике со средними показателями безработицы по Российской Федерации (таблица 3).

В Чеченской Республике очень остро стояла проблема занятости населения. В 2010 году в Чеченской Республике доля безработного населения составляла 35\%, в 2010 году - 43,3\%. В дальнейшем наблюдается положительная динамика, идет устойчивое снижение уровня безработицы - до 13,5\% в 2019 году.

Анализ таблицы 4 говорит о самом высоком уровне безработицы в СКФО - 11,1\% (в 2017 году - 11,0\%, в 2018 году - 10,6\%), но даже здесь наиболее остро эта проблема стоит в Республике Ингушетия - в 2019 году уровень безработицы

Таблица 2. Уровень экономической активности населения (в процентах; в среднем за год)

\begin{tabular}{|l|c|c|c|c|c|c|c|c|c|c|}
\hline & 2008 & 2009 & 2010 & 2011 & 2012 & 2013 & 2014 & 2015 & 2016 & 2017 \\
\hline Российская Федерация & 67,7 & 67,8 & 67,7 & 68,3 & 68,7 & 68,5 & 68,9 & 69,1 & 69,5 & 69,1 \\
\hline $\begin{array}{l}\text { Северо-Кавказский } \\
\text { федеральный округ }\end{array}$ & 63,6 & 64,6 & 64 & 64,6 & 65,3 & 65,8 & 66,1 & 65,3 & 65,6 & 65,5 \\
\hline Республика Дагестан & 67,2 & 65,3 & 62,7 & 65,5 & 63,6 & 63,2 & 63,1 & 61,7 & 62,7 & 63,1 \\
\hline Республика Ингушетия & 53,4 & 64,3 & 64,8 & 67,8 & 69,1 & 68,7 & 70,4 & 72,3 & 72,8 & 77,1 \\
\hline $\begin{array}{l}\text { Кабардино-Балкарская } \\
\text { Республика }\end{array}$ & 58,7 & 59,5 & 58,1 & 56,6 & 59,7 & 65,6 & 68,1 & 67,3 & 68,1 & 68,3 \\
\hline $\begin{array}{l}\text { Карачаево-Черкесская } \\
\text { Республика }\end{array}$ & 61,1 & 66,2 & 64,7 & 65,4 & 67,4 & 63,9 & 65,2 & 63,1 & 62,6 & 61,1 \\
\hline $\begin{array}{l}\text { Республика Северная } \\
\text { Осетия-Алания }\end{array}$ & 66,1 & 68,5 & 70 & 67,6 & 67,2 & 65,9 & 65,8 & 64,4 & 63,6 & 65,7 \\
\hline Чеченская Республика & 59,4 & 67,6 & 66,3 & 66,2 & 70,7 & 76,9 & 73,9 & 70,9 & 69,9 & 68,4 \\
\hline Ставропольский край & 64,9 & 63,5 & 64,4 & 64,2 & 65,1 & 64,1 & 65,0 & 65,6 & 65,8 & 64,6 \\
\hline
\end{tabular}

Таблица 3. Среднегодовая численность занятых в экономике (тысяч человек)

\begin{tabular}{|l|c|c|c|c|c|c|c|c|c|c|}
\hline & 2008 & 2009 & 2010 & 2011 & 2012 & 2013 & 2014 & 2015 & 2016 & 2017 \\
\hline Российская Федерация & 68473,6 & 67343,3 & 67493,4 & 67643,6 & 67968,3 & 67901,0 & 67813,3 & 72424,9 & 72065,2 & 71842,7 \\
\hline $\begin{array}{l}\text { Северо-Кавказский } \\
\text { федеральный округ }\end{array}$ & 3238,1 & 3256,2 & 3314,6 & 3374,3 & 3397,2 & 3423,3 & 3464,1 & 3745,8 & 3778,9 & 3839,6 \\
\hline Республика Дагестан & 941,4 & 942,0 & 949,0 & 966,6 & 981,4 & 995,2 & 1011,7 & 1063,4 & 1066,8 & 1091,5 \\
\hline Республика Ингушетия & 66,3 & 65,5 & 68,3 & 68,7 & 70,2 & 72,7 & 77,4 & 153,2 & 162,3 & 179,4 \\
\hline $\begin{array}{l}\text { Кабардино-Балкарская } \\
\text { Республика }\end{array}$ & 311,2 & 310,1 & 309,9 & 308,8 & 308,1 & 307,0 & 305,8 & 357,0 & 358,9 & 362,6 \\
\hline $\begin{array}{l}\text { Карачаево-Черкесккая } \\
\text { Республика }\end{array}$ & 166,5 & 166,7 & 170,6 & 172,8 & 173,1 & 171,7 & 169,1 & 173,3 & 171,7 & 169,2 \\
\hline $\begin{array}{l}\text { Республика Северная } \\
\text { Осетия-Алания }\end{array}$ & 296,0 & 298,1 & 299,3 & 299,2 & 298,5 & 298,9 & 296,8 & 294,7 & 287,2 & 289,7 \\
\hline Чеченская Республика & 237,9 & 256,2 & 281,0 & 312,9 & 327,8 & 342,4 & 365,8 & 488,7 & 490,0 & 513,5 \\
\hline Ставропольский край & 1218,8 & 1217,6 & 1236,5 & 1245,3 & 1238,0 & 1235,4 & 1237,5 & 1215,5 & 1242,0 & 1233,7 \\
\hline
\end{tabular}


Таблица 4. Уровень безработицы в СКФО (в процентах; в среднем за год)

\begin{tabular}{|l|c|c|c|c|c|c|c|c|c|c|}
\hline & 2010 & 2011 & 2012 & 2013 & 2014 & 2015 & 2016 & 2017 & 2018 & 2019 \\
\hline Российская Федерация & 7,3 & 6,5 & 5,5 & 5,5 & 5,2 & 5,6 & 5,5 & 5,2 & 4,8 & 4,6 \\
\hline $\begin{array}{l}\text { Северо-Кавказский } \\
\text { федеральный округ }\end{array}$ & 16,5 & 14,5 & 13,1 & 13,0 & 11,2 & 11,1 & 11,0 & 11,0 & 10,6 & 11,1 \\
\hline Республика Дагестан & 14,8 & 12,7 & 11,7 & 11,6 & 10,2 & 10,8 & 10,9 & 12,0 & 11,6 & 13,0 \\
\hline Республика Ингушетия & 49,7 & 48,1 & 47,7 & 43,7 & 29,8 & 30,5 & 30,2 & 27,0 & 26,6 & 26,8 \\
\hline $\begin{array}{l}\text { Кабардино-Балкарская } \\
\text { Республика }\end{array}$ & 12,7 & 10,5 & 8,9 & 10,5 & 9,5 & 10,1 & 10,3 & 10,5 & 10,5 & 10,8 \\
\hline $\begin{array}{l}\text { Карачаево-Черкесская } \\
\text { Республика }\end{array}$ & 10,3 & 9,8 & 8,9 & 9,8 & 13 & 15,1 & 14,4 & 13,5 & 12,1 & 11,8 \\
\hline $\begin{array}{l}\text { Республика Северная } \\
\text { Осетия-Алания }\end{array}$ & 9,7 & 8,3 & 7,9 & 8,1 & 8,6 & 9,3 & 9,9 & 11,8 & 10,5 & 12,2 \\
\hline Чеченская Республика & 43,3 & 37,3 & 29,8 & 26,9 & 21,5 & 17,1 & 15,8 & 14,0 & 13,7 & 13,5 \\
\hline Ставропольский край & 6,9 & 6,0 & 5,4 & 5,6 & 5,3 & 5,6 & 5,7 & 5,2 & 5,0 & 4,9 \\
\hline
\end{tabular}

здесь самый высокий в России - 26,8\%. Уровень безработицы на Северном Кавказе в более, чем два раз выше, чем в России. В Чеченской Республике уровень безработицы показал рекордное снижение - с 43.3\% в 2010 году до 13,5\% в 2019 году. В других республиках СКФО этот показатель находится в интервале от 4,9\% до 13,5\%.

Хотя ситуация с безработицей в СКФО довольно сложная, но динамика на рынке труда позитивная.

Как показывает рисунок 1, по сравнению с 2017 годом и 2018 годом ситуация несколь- ко ухудшилась как во всем Северо-Кавказском федеральном округе, так и в некоторых его регионах - Республика Северная Осетия-Алания, Республика Дагестан, Кабардино-Балкарская Республика.

Имеются существенные различия в возрастной структуре безработных в Чеченской Республике со среднероссийскими значениями. В Российской Федерации доля безработных в возрасте с 20 до 29 лет равна 35\%. В Чеченской Республике этот показатель превышает 50\% для указанной возрастной группы.

\section{Динамика уровня безработицы в регионах СКФО}

18

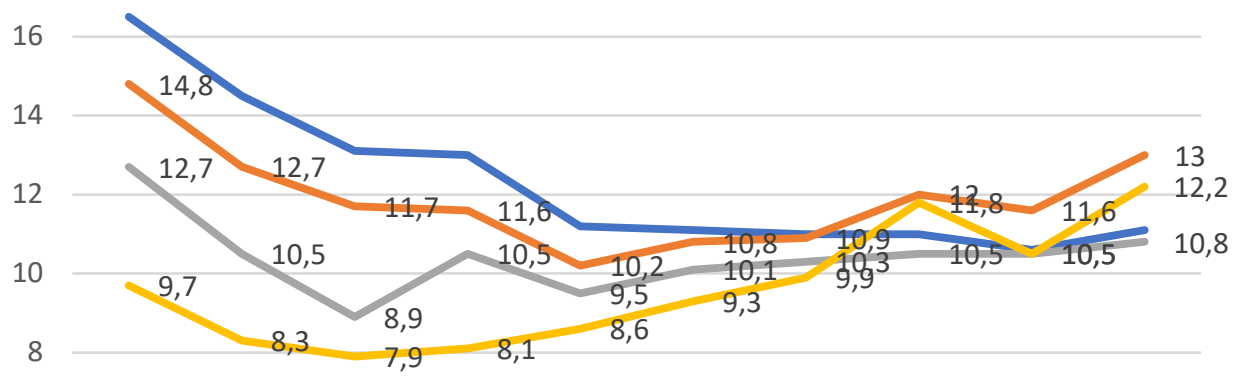

4

2

0

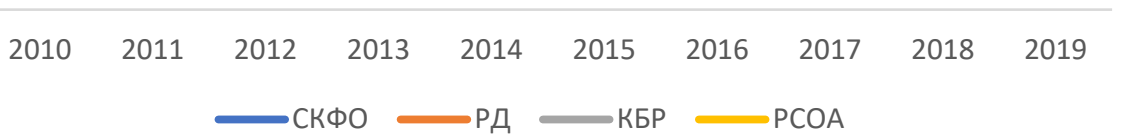

Рисунок 1. Динамика уровня безработицы в регионах СКФО 
Доля безработных в возрастной группе от 15 до 19 лет в Чеченской Республике превышает $27 \%$ (для сравнения, по Российской Федерации 4\%). Совокупная доля безработных в возрастных группах от 30 до 39 лет и от 40 до 49 лет в Чеченской Республике не превышает 18\% (в Российской Федерации около 40\%).

В настоящее время рынок труда в СКФО, как и во всей России, не сбалансирован. Об этом свидетельствуют серьезные структурные перекосы как в спросе, так и в предложении.

Следствием такой структуры безработных по возрасту можно считать и различия среднего возраста безработных $-25,8$ лет в Чеченской Республике в 2017 году против 35,8 лет в среднем по России.

В настоящее время российский рынок труда не сбалансирован, о чем свидетельствуют серьезные структурные перекосы как в спросе, так и в предложении.

Важнейшим показателем рынка труда является уровень безработицы.

Единственным фактором, сдерживающим рост безработицы с точки зрения динамичных потоков на рынке труда, является значительное увеличение доли безработных, переехавших в экономически неактивное население.

Многие молодые безработные в СКФО имеют профессиональное образование, но не могут найти работу из-за отсутствия профильных рабочих мест.

О подлинной напряженности на рынке труда свидетельствует тот факт, что в апреле 2018 года нагрузка безработного населения, зарегистрированного в государственных учреждениях службы занятости Чеченской Республики, на 100 объявленных вакансий составляла 2236 человек. А в апреле 2019 года нагрузка незанятого населения, зарегистрированного в службе занятости, на 100 заявленных вакансий составила уже 2513 человек, что говорит о росте реальной напряженности на рынке труда.

Одним из факторов высокой напряженности можно считать естественное пополнение трудовых ресурсов непропорционально количеству создаваемых новых рабочих мест.

Необходима комплексная федеральная целевая программа, ориентированная на поддержание региональной занятости и регулирование напряженности на рынке труда.

\section{Библиографический список}

1. Доклад «Социально-экономическое положение Чеченской Республики» за январь-апрель 2018 г. [электронный ресурс]: - Режим доступа: http://chechenstat.gks.ru/wps/wcm/connect/rosstat_ts/chechenstat/ru/ publications/official_publications/electronic_versions/

2. Елисеева И.И., Статистика. Проспект, 2015. С. 289-293

3. Занятость и безработица в марте 2018 года [электронный ресурс]: - Режим доступа: http://www.gks.ru/wps/ wcm/connect/rosstat_main/rosstat/ru/statistics/wages/labour_force/

4. Занятость и безработица. Государственная политика занятости [электронный ресурс]: - Режим доступа: https://www.bestreferat.ru/referat-217213.html

5. Кадыров: высокий темп роста населения Чечни должен учитываться при формировании бюджета [электронный ресурс]: - Режим доступа: http://tass.ru/ekonomika/4596839

6. Кейнс Дж.М. «Общая теория занятости, процента и денег».- М.: Гелиос АРВ, 2002._ 352c.

7. Регионы России. Социально-экономические показатели. 2019: [электронный ресурс]: - Режим доступа: http://www.gks.ru/bgd/regl/b18_14p/Main.htm 